\title{
ANALISIS BEBAN-PENURUNAN PADA PONDASI TIANG BOR BERDASARKAN HASIL UJI BEBAN TIANG TERINSTRUMENTASI DAN PROGRAM GEO5
}

\author{
Andrias Suhendra Nugraha, Angel Refanie \\ Program Studi Teknik Sipil, Universitas Kristen Maranatha \\ Jalan Prof. drg. Suria Sumantri, MPH., No. 65 Bandung, 40164 \\ Email: andrias.sn@eng.maranatha.edu, angelrefanie@gmail.com
}

\begin{abstract}
ABSTRAK
Pondasi tiang bor merupakan salah satu jenis pondasi dalam. Pada pondasi tiang bor yang menerima beban aksial, beban didistribusikan ke tanah melalui tahanan ujung dan tahanan selimut tiang. Uji beban aksial tiang terinstrumentasi yang dilengkapi instrumentasi berupa VWSG (Vibrating Wire Strain Gauge) dan tell-tale extensometer dilakukan untuk mengetahui perilaku distribusi beban dan beban-penuruan dari pondasi tiang bor. Penelitian ini bertujuan untuk menganalisis beban-penurunan pada pondasi tiang bor akibat pembebanan aksial. Analisis dilakukan pada pondasi tiang bor dengan diameter $1,0 \mathrm{~m}$, panjang 59,3 m, pada tanah yang terdiri atas medium silty clay, stiff silty clay, dan hard clay. Pembebanan saat uji beban dilakukan hingga $300 \%$ dari beban kerja (working load) sebesar 600 ton melalui 6 siklus pembebanan. Hasil uji beban terinstrumentasi menunjukkan bahwa penurunan pondasi tiang bor adalah sebesar 3,8 $\mathrm{mm}$ saat beban uji mencapai 600 ton (working load). Sementara hasil dari program GEO5 saat beban uji 600 ton, penurunan pondasi tiang bor adalah sebesar $16.3 \mathrm{~mm}$.
\end{abstract}

kata kunci: beban-penurunan, tiang bor, uji beban tiang terinstrumentasi

\begin{abstract}
Bored pile is one kind of deep foundation On bored pile subjected to axial load, the load is distributed to the ground through end bearing and skin friction of the pile. Instrumented axial pile loading test performed on bored pile using VWSG (Vibrating Wire Strain Gauge) and tell-tale extensometer to analyze load distribution and load-settlement behavior. This research aims to analyze load-settlement on bored pile due to axial loading. Analysis was performed on bored pile which is 1,0 m in diameter, 59,3 m in length, on the soil consist of medium silty clay, stiff silty clay, and hard clay. Axial load subjected to bored pile performed up to 300\% of the 600 tons working load with 6 loading cycles. When loading test reach 600 ton (working load), settlement of bored pile from instrumented pile load test is $3,8 \mathrm{~mm}$, meanwhile pile settlement from GEO5 program is $16,3 \mathrm{~mm}$.
\end{abstract}

keywords: bored pile, instrumented pile load test, load-settlement

\section{PENDAHULUAN}

Seiring dengan berkembangnya pembangunan infrastruktur di Indonesia, pondasi tiang bor semakin banyak digunakan diantaranya untuk bangunan gedung, jembatan, dan soldier pile. Pondasi tiang bor merupakan salah satu jenis pondasi dalam dan berfungsi menyalurkan beban bangunan pada lapisan tanah dengan kapasitas daya dukung yang memenuhi (bearing stratum). Keunggulan dari penggunaan pondasi tiang bor yaitu kemampuannya menahan beban bangunan yang besar, biaya konstruksi yang relatif lebih ekonomis, kemudahan 
dalam menyesuaikan panjang dan diameter tiang yang dibutuhkan, serta minimnya getaran dan suara yang ditimbulkan pada saat pelaksanaan.

Pada pondasi tiang bor yang menerima beban aksial, beban didistribusikan ke tanah oleh tahanan selimut (skin friction resistance) dan tahanan ujung (end bearing resistance) tiang melalui suatu mekanisme transfer beban. Tahanan selimut dan tahanan ujung tiang bekerja sampai mencapai keadaan ultimit yang kemudian menghasilkan daya dukung ultimit. Daya dukung ultimit tiang perlu diverifikasi oleh hasil uji beban tiang. Uji beban tiang umumnya bertujuan untuk memastikan atau memodifikasi desain pondasi tiang pada saat konstruksi agar daya dukung sesuai rencana.

Uji beban tiang dapat dilengkapi oleh instrumen seperti Vibrating Wire Strain Gauge (VWSG) dan tell-tale extensometer. Dengan adanya instrumentasi dapat diketahui perilaku pondasi tiang bor yang tidak dapat dianalisis dari hasil uji beban tiang seperti pada ASTM 1141-81. Dengan menganalisis hasil uji beban tiang terinstrumentasi, dapat dihasilkan kurva transfer beban dan kurva bebanpenurunan. Transfer beban pada pondasi tiang bor menunjukkan seberapa besar beban yang didistribusikan pada tanah oleh tahanan selimut dan tahanan ujung tiang. Melalui analisis transfer beban juga dapat diketahui kondisi dimana beban telah termobilisasi penuh.

Penggunaan instrumentasi pada pengujian tiang menjadi salah satu metode yang dapat diandalkan untuk mengetahui informasi tentang interaksi tanah dengan tiang. Di samping itu, dengan adanya program (software) geoteknik akan memudahkan dalam melakukan analisis pondasi tiang untuk menghasilkan output yang diperlukan. Berdasarkan hal tersebut di atas, penelitian ini bertujuan untuk meneliti beban-penurunan pada pondasi tiang bor akibat pembebanan aksial berdasarkan hasil uji beban tiang terinstrumentasi yang kemudian dibandingkan dengan output dari program GEO5.

\subsection{TUJUAN PENELITIAN}

Tujuan penelitian adalah sebagai berikut:

1. Melakukan analisis beban-penurunan pada pondasi tiang bor menggunakan hasil uji beban tiang terinstrumentasi dan program GEO5. 
2. Membandingkan output berupa kurva beban-penurunan dari hasil uji beban tiang terinstrumentasi dan program GEO5.

\subsection{RUANG LINGKUP PENELITIAN}

Ruang lingkup penelitian adalah sebagai berikut:

1. Lokasi pengujian pondasi tiang bor berada di kota Jakarta.

2. Data tanah yang digunakan berupa jenis tanah dan konsistensi tanah di lokasi pengujian sampai pada kedalaman tiang bor dari konsultan CEP LTD.

3. Data yang digunakan dalam penelitian berupa hasil uji beban tiang terinstrumentasi pada pondasi tiang bor berdiameter $1 \mathrm{~m}$, panjang 59,3 m, dengan cut-off level (COL) pada kedalaman $18 \mathrm{~m}$ di bawah permukaan tanah.

4. Tiang bor dipasang pada kedalaman 59,3 m di bawah permukaan tanah dan sedalam $18 \mathrm{~m}$ di atas COL merupakan debonded zone.

5. Pondasi tiang bor yang diuji menggunakan beton mutu Grade 30 (nilai $\mathrm{E}_{\mathrm{c}}$, Tabel 7.1, BS 8110, Part 2, 1985) dan didesain untuk memikul beban kerja 600 ton.

6. Instrumen yang dipasang pada pondasi tiang bor adalah 18 buah VWSG pada kedalaman $18 \mathrm{~m}, 24 \mathrm{~m}, 30 \mathrm{~m}, 36 \mathrm{~m}, 42 \mathrm{~m}, 47,5 \mathrm{~m}, 52,5 \mathrm{~m}$, dan $57,5 \mathrm{~m}$ serta 2 buah tell-tale extensometer pada kedalaman $18 \mathrm{~m}$ dan 57,5 m.

7. Jenis pembebanan yang dilakukan untuk menguji pondasi tiang bor adalah Slow Mantained Load Test Method (SM) sesuai dengan ASTM 1143-81.

8. Program yang digunakan untuk analisis adalah GEO5 versi 19.

9. Nilai Oedometric Modulus ( $\mathrm{E}_{\mathrm{oed}}$ ) pada input program GEO5 adalah $30 \mathrm{MPa}$ dan nilai Poisson's ratio (v) adalah 0,35 untuk semua konsistensi tanah yang digunakan.

10. Analisis dilakukan terhadap beban-penurunan pada pondasi tiang bor.

11. Penurunan yang ditinjau dari kurva beban-penurunan adalah pada beban kerja 600 ton.

\section{DATA TANAH DAN SPESIFIKASI TIANG}

Jenis tanah di titik pengujian adalah tanah kohesif berupa lempung (clay) dan lempung kelanauan (silty clay) dengan konsistensi medium, stiff, dan hard. 
Jenis tanah dan konsistensinya sampai dengan kedalamaan pemasangan pondasi tiang bor ditunjukkan pada Gambar 1.

Data tanah di titik pengujian merupakan tanah butir halus dan memiliki nilai sudut geser dalam $(\Phi)=0^{\circ}$. Nilai $\mathrm{N}_{\mathrm{SPT}}$ yang digunakan dalam analisis terdapat pada Tabel 1.

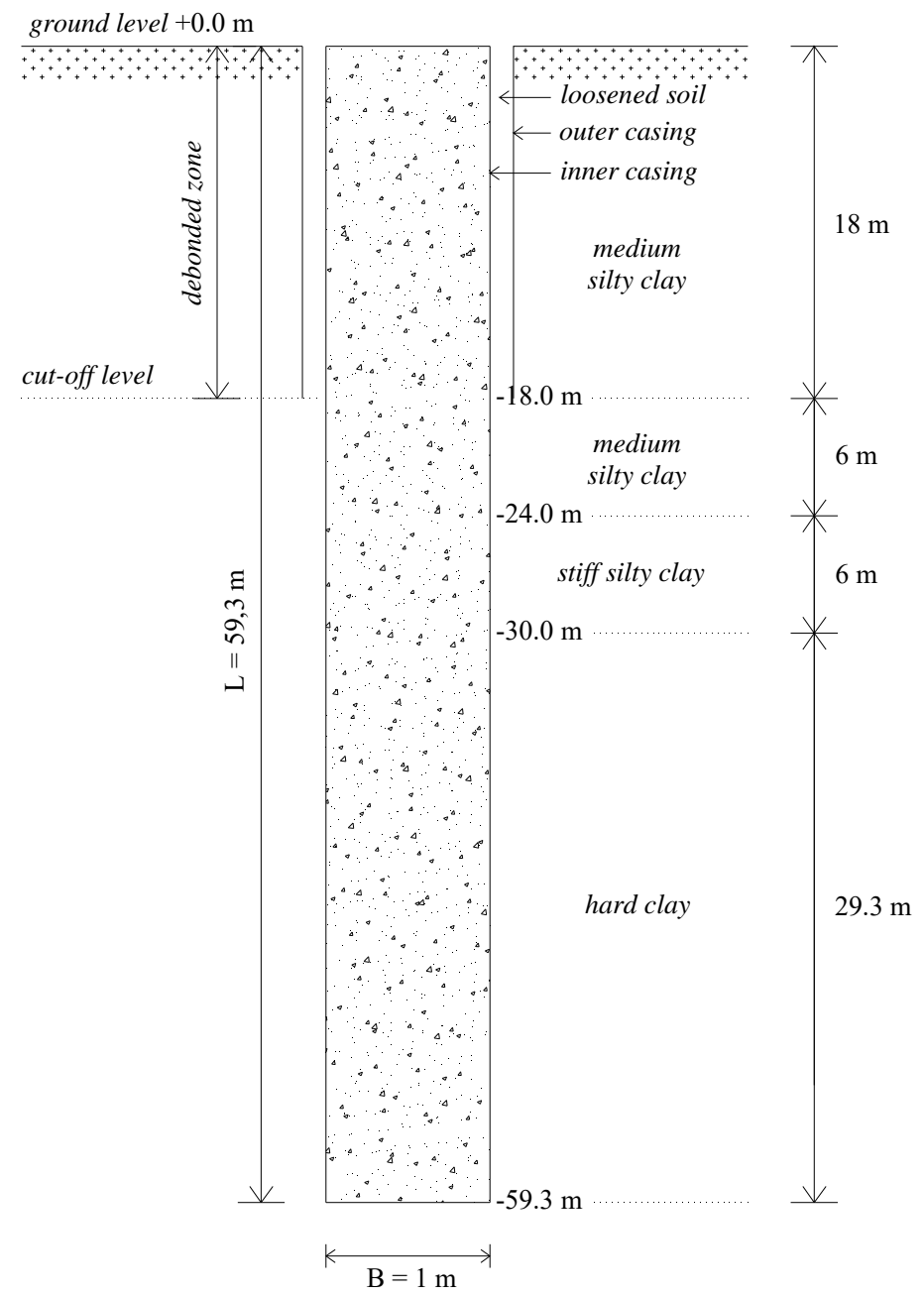

Gambar 1. Jenis Tanah dan Dimensi Pondasi Tiang Bor

Tabel 1. $\mathrm{N}_{\mathrm{SPT}}$, Jenis Tanah dan Konsistensi Tanah

\begin{tabular}{|c|c|c|c|}
\hline Lapisan & Jenis Tanah & Konsistensi Tanah & $\begin{array}{c}\mathrm{N}_{\mathrm{SPT}} \\
\text { (blows/ft) }\end{array}$ \\
\hline 1 & Silty clay & Medium & 4 \\
\hline 2 & Silty clay & Stiff & 8 \\
\hline 3 & Clay & Hard & 33 \\
\hline
\end{tabular}


Pondasi tiang bor yang diuji berbentuk lingkaran berdiameter $1 \mathrm{~m}$ yang dipasang pada kedalaman 59,3 m dengan cut-off level (COL) pada kedalaman 18 $\mathrm{m}$ di bawah permukaan tanah. Sedalam $18 \mathrm{~m}$ di atas cut-off level merupakan debonded zone. Dimensi tiang bor ditunjukkan pada Gambar 1. Lubang bor dibuat menggunakan rotary auger dan material beton dimasukkan ke dalam lubang bor dengan menggunakan pipa tremie.

Mutu beton yang digunakan pada pondasi tiang bor adalah Grade $30\left(\mathrm{E}_{\mathrm{c}}\right.$ bervariasi dengan kisaran 20-33 kN/mm²) berdasarkan standar BS 8110, Part 2, 1985. Pada awal uji pembebanan, pondasi tiang bor berumur 2 bulan. Pondasi tiang bor didesain untuk memikul beban kerja 600 ton dan dibebani sampai dengan 300\% dari beban kerja melalui 6 siklus pembebanan. Metode uji pembebanan yang digunakan adalah Slow Mantained Load Test Method (SM).

Satu hari setelah pelaksanaan pondasi tiang bor, tanah di atas COL diregangkan dengan mengebor sekeliling pondasi tiang bor menggunakan bor diameter 0,5 m yang diikuti dengan pemasangan casing baja sepanjang $18 \mathrm{~m}$.

\section{UJI BEBAN TIANG TERINSTRUMENTASI}

Untuk mengetahui perilaku tiang terhadap beban aksial yang diberikan, pengujian tiang perlu dilengkapi dengan instrumen. Uji pembebanan tiang terinstrumentasi bisa diartikan sebagai pengujian tiang yang dikombinasikan dengan instrumentasi strain gauges dan tell-tale extensometer. Dengan adanya instrumentasi, dapat diketahui informasi mengenai pergerakan kaki tiang, deformasi sepanjang tiang, dan distribusi beban sepanjang tiang selama pengujian. Pengujian tiang dengan instrumentasi ditunjukkan pada Gambar 2.

Pengukuran yang dilakukan pada uji beban tiang terdiri dari pengukuran pergerakan tiang baik di kepala tiang maupun kaki tiang dan pengukuran peningkatan regangan di sepanjang tiang. Pengukuran terhadap pergerakan tiang dibutuhkan hampir pada semua uji beban tiang. Instrumen yang umum digunakan untuk mengukur pergerakan tiang adalah dial gauge. Paling sedikit digunakan dua buah dial gauges untuk mengukur pergerakan tiang, yang kemudian hasil pengkurannya dirata-rata. Ketelitian dari dial gauge yang digunakan minimal 0,01 inci $(0,25 \mathrm{~mm})$. 


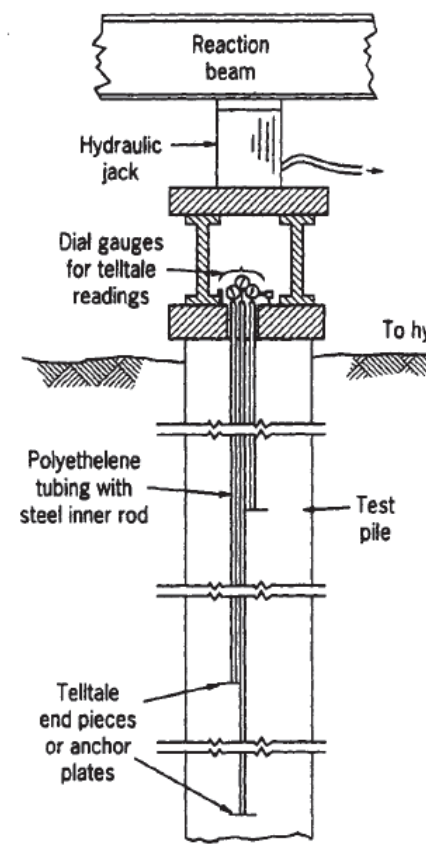

(a)
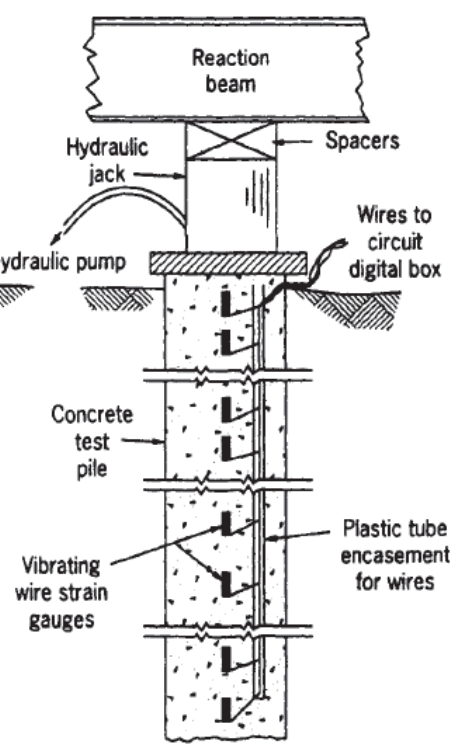

(b)

Gambar 2. Pengujian Tiang dengan Instrumentasi (a) Tell-tale Extensometer, (b) Vibrating Wire Strain Gauge

(Sumber: Prakash, 1990)

Pengukuran peningkatan regangan digunakan untuk menentukan distribusi transfer beban dari tiang ke tanah, yang umumnya pengukuran ini bersifat optional dalam uji beban tiang. Instrumentasi yang biasanya ditambahkan pada tiang yang diuji berupa:

1. Vibrating Wire Strain Gauges (VWSG) merupakan instrumentasi yang dipasangkan pada tiang uji dengan tujuan untuk mengukur regangan (strain) dan mengetahui besar pendistribusian beban pada tiap kedalaman tiang yang telah ditentukan. VWSG dipasang pada tulangan tiang uji. Instrumentasi VWSG ditunjukkan pada Gambar 3. Sensor VWSG dihubungkan dengan kabel ke permukaan tiang dan hasil bacaan VWSG dimonitor melalui portable LCD. Prinsip kerja VWSG adalah mengukur regangan berdasarkan perubahan frekuensi pada setiap beban yang berbeda. Setiap perubahan yang terjadi mengindikasikan perubahan regangan yang terjadi. VWSG mengukur besarnya regangan pada kedalaman tertentu pada tiang uji. Dengan diketahuinya besarnya regangan, luas penampang tiang, dan modulus elastisitas tiang, dapat diketahui besarnya beban melalui persamaan 1 .

\section{QwWse $=\mathrm{AEs}$}


dimana: $\mathrm{Q}_{V W S G} \quad=$ beban pada lokasi pemasangan VWSG

A $=$ luas penampang tiang bor

$\mathrm{E}=$ modulus elastisitas tiang bor

$\varepsilon \quad=$ regangan (bacaan VWSG)

Sebelum mengetahui besarnya beban, perlu dicari parameter modulus elastisitas tiang pada level VWSG yang telah dipasang karena besarnya modulus elastisitas beton tidak selalu tetap seperti material baja.

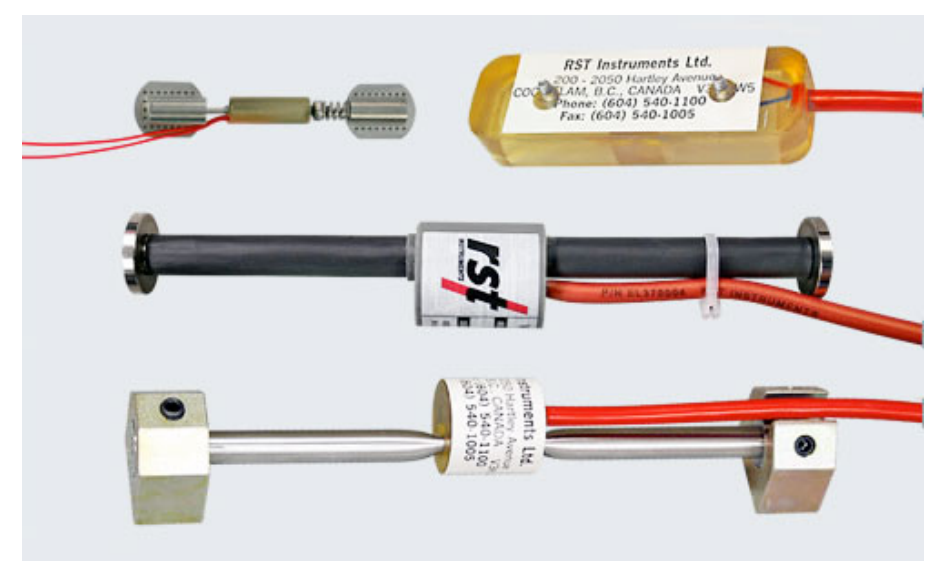

Gambar 3. Vibrating Wire Strain Gauge (Sumber: geonor.com)

2. Tell-tale extensometer merupakan instrumentasi berupa stainless steel rod dalam pipa polyvinyl chloride $(P V C)$ atau menempel pada tulangan tiang yang dipasang pada beberapa lokasi sepanjang tiang seperti ditunjukkan pada Gambar 4. Tell-tale extensometer berukuran sekitar 5-10 $\mathrm{mm}$ dan dipasang dari kedalaman tertentu sampai ke kepala tiang. Biasanya ditempatkan pada $C O L$ tiang dan di dekat ujung tiang uji. Tujuan pemasangan tell-tale extensometer ini untuk mengukur perbedaan penurunan tiang dan mengkalibrasi penurunan di kepala tiang. Pengukuran penurunan tiang dengan tell-tale extensometer diukur menggunakan dial gauge dengan ketelitian 0,001 inci $(0,025 \mathrm{~mm})$. Umumnya penurunan yang terjadi pada tiang uji tidak sama di setiap kedalaman dan bacaan tell-tale extensometer mengacu pada kepala tiang. Dengan mencatat lokasi kedalaman pemasangan dan mengukur pergerakan pada setiap tell-tale extensometer, beban di tengah kedua kedalaman tell-tale extensometer dapat dihitung dengan persamaan 2.

$$
Q_{T T}=\mathrm{AE}\left(\frac{\Delta}{2}\right)
$$


dimana: $\mathrm{Q}_{\mathrm{TT}} \quad=$ beban di tengah antara dua tell-tale extensometer

$\Delta \mathrm{L}_{\mathrm{TT}}=$ selisih perpindahan antara dua tell-tale extensometer

$\mathrm{L}_{\mathrm{TT}}=$ jarak antara dua tell-tale extensometer

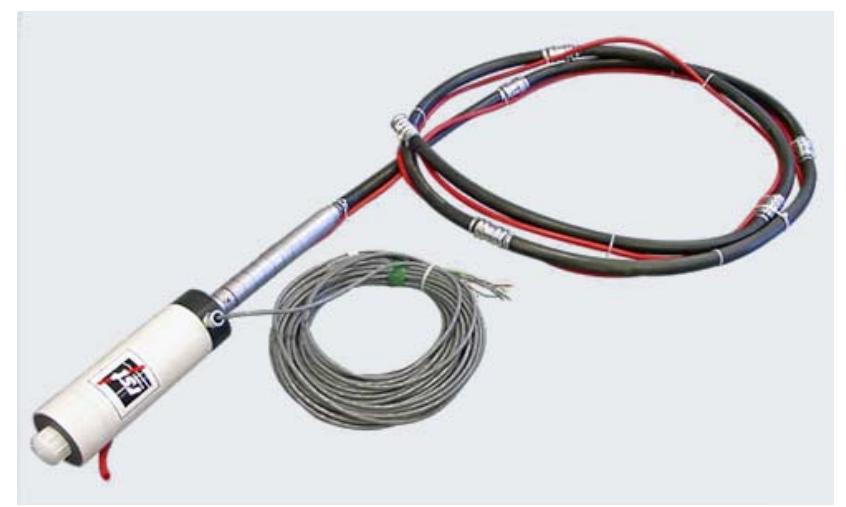

Gambar 4. Tell-tale Extensometer

(Sumber: geonor.com)

Dengan melakukan check compatibility penurunan dari tell-tale extensometer dan bacaan VWSG, dapat dihitung penurunan untuk setiap segmen kedalaman dengan persamaan 3.

$$
\mathrm{z}_{\mathrm{si}}=\mathrm{z}_{\mathrm{si}-1}+\left(\mathrm{Q}_{\mathrm{i}}+\mathrm{Q}_{\mathrm{i}-1}\right)\left(\mathrm{d}_{\mathrm{i}}-\mathrm{d}_{\mathrm{i}-1}\right) / 2 \mathrm{E} \mathrm{A}
$$

dimana:

$$
\begin{aligned}
& \mathrm{Z}_{\mathrm{si}}=\text { perpindahan pada segmen } \mathrm{i} \\
& \mathrm{Q}_{\mathrm{i}}=\text { beban pada segmen } \mathrm{i} \\
& \mathrm{d}_{\mathrm{i}}=\text { kedalaman pemasangan VWSG sampai dengan segmen } \mathrm{i}
\end{aligned}
$$

Sedangkan tahanan selimut tiang pada setiap segmen dapat dihitung dengan persamaan 4 .

$$
\left(f_{s}\right)_{i}=\left(Q_{i-1}-Q_{i}\right) /\left(\pi B\left(d_{i}-d_{i-1}\right)\right)
$$

dimana:

$$
\begin{aligned}
& \left(\mathrm{f}_{\mathrm{s}}\right)_{\mathrm{i}}=\text { tahanan selimut tiang rata-rata pada segmen } \mathrm{i} \\
& \mathrm{B}=\text { diameter tiang }
\end{aligned}
$$

Instrumen yang digunakan pada uji beban tiang terinstrumentasi adalah Vibrating Wire Strain Gauge (VWSG) dan tell-tale extensometer. 18 buah VWSG 
(A1, A2, B1, B2, C1, C2, D1, D2, E1, E2, F1, F2, G1, G2, H1, H2, H3, dan H4) dan 2 buah tell-tale extensometer (TT1 dan TT2) dipasang pada pondasi tiang bor untuk memonitor perilaku pondasi tiang bor selama dilakukan pembebanan. Pada setiap kedalaman dipasang 2 buah VWSG dan di dekat ujung tiang dipasang 4 buah VWSG. Lokasi pemasangan instrumen pada tiang bor ditunjukkan pada Gambar 5. Beban yang diberikan dihitung menggunakan load cells berkapasitas 8 $\times 250$ ton.

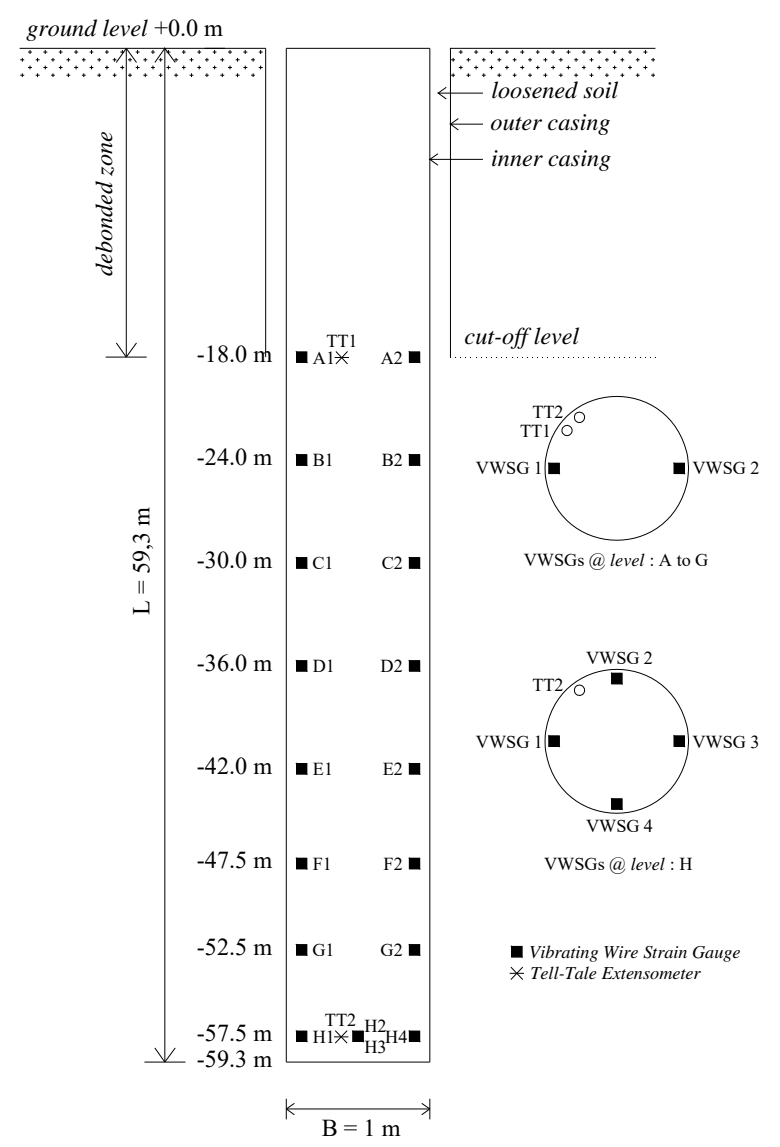

Gambar 5. Lokasi Pemasangan Instrumen pada Tiang Bor

\section{HASIL ANALISIS}

Bacaan tell-tale extensometer terdapat pada Tabel 2. Tell-tale extensometer TT-1 dipasang pada elevasi $18 \mathrm{~m}$ di bawah permukaan tanah untuk mengukur perpidahan tiang di kepala tiang dan tell-tale extensometer TT-2 dipasang pada elevasi 57,5 di bawah permukaan tanah untuk mengukur perpindahan tiang di bagian dekat ujung tiang. Bacaan tell-tale extensometer TT-1 
menjadi tidak menentu karena mengalami kerusakan pada siklus pembebanan ketiga.

Tabel 2. Hasil Analisis Beban-Penurunan Berdasarkan Uji Beban Tiang Terinstrumentasi

\begin{tabular}{|c|c|c|}
\hline \multirow{2}{*}{$\begin{array}{c}\text { Beban } \\
\text { (ton) }\end{array}$} & \multicolumn{2}{|c|}{$\begin{array}{c}\text { Penurunan Berdasarkan } \\
\text { Tell-tale Extensometer }\end{array}$} \\
\cline { 2 - 3 } & $\begin{array}{c}\text { TT-1 } \\
(\mathrm{mm})\end{array}$ & $\begin{array}{c}\text { TT-2 } \\
(\mathrm{mm})\end{array}$ \\
\hline 169,2 & 0,82 & 0.84 \\
\hline 297,4 & 1,36 & 1,40 \\
\hline 461,4 & 2,01 & 2,46 \\
\hline 620,3 & 3,24 & 3,94 \\
\hline 754,8 & 4,08 & 6,14 \\
\hline 896,6 & 4,74 & 7,58 \\
\hline 1091,2 & & 13,05 \\
\hline 1249,3 & & 11,52 \\
\hline 1328,4 & & 11,77 \\
\hline 1526,4 & & 12,72 \\
\hline 1672,9 & & 13,24 \\
\hline 1823,5 & & 14,08 \\
\hline
\end{tabular}

(Sumber: Data Uji Beban Tiang Terinstrumentasi CEP LTD)

Parameter tanah yang digunakan untuk input program GEO5 terdapat pada Tabel 3.

Tabel 3. Parameter Tanah yang Digunakan pada Input Program GEO5

\begin{tabular}{|c|c|c|c|}
\hline \multirow{2}{*}{ Parameter } & \multicolumn{3}{|c|}{ Konsistensi } \\
\cline { 2 - 4 } & Medium & Stiff & Hard \\
\hline Unit weight, $\gamma\left(\mathrm{kN} / \mathrm{m}^{3}\right)$ & 18,10 & 19,90 & 21,5 \\
\hline Cohesion of soil, $\mathrm{c}_{\mathrm{u}}(\mathrm{kPa})$ & 23,90 & 48,50 & 199,90 \\
\hline Angle of dispersion, $\beta\left({ }^{\circ}\right)$ & 0 & 0 & 0 \\
\hline
\end{tabular}

Besar beban-penurunan dari analisis dengan menggunakan program GEO5 terdapat pada Tabel 4. 
Tabel 4. Hasil Analisis Beban-Penurunan Berdasarkan Program GEO5

\begin{tabular}{|c|c|}
\hline $\begin{array}{c}\text { Beban } \\
\text { (ton) }\end{array}$ & $\begin{array}{c}\text { Penurunan } \\
(\mathrm{mm})\end{array}$ \\
\hline 0 & 0 \\
\hline 181,81 & 5 \\
\hline 363,63 & 10 \\
\hline 545,44 & 15 \\
\hline 727,25 & 20 \\
\hline 909,06 & 25 \\
\hline
\end{tabular}

Kurva beban terhadap penurunan diperoleh dengan penggambaran data tell-tale extensometer dan menganalisis pondasi tiang menggunakan program GEO5 seperti ditunjukkan pada Gambar 6.

Berdasarkan Gambar 6, besar penurunan pada saat beban kerja (WL) 600 ton dari hasil uji beban tiang terinstrumentasi adalah sebesar 3,8 $\mathrm{mm}$ dan dari program GEO5 adalah sebesar 16,3 $\mathrm{mm}$. Perbedaan penurunan hasil uji beban tiang terinstrumentasi terhadap program GEO5 adalah sebesar 76,7\%. Hal ini menunjukkan analisis penurunan pondasi tiang dengan menggunakan program GEO5 adalah analisis konservatif.

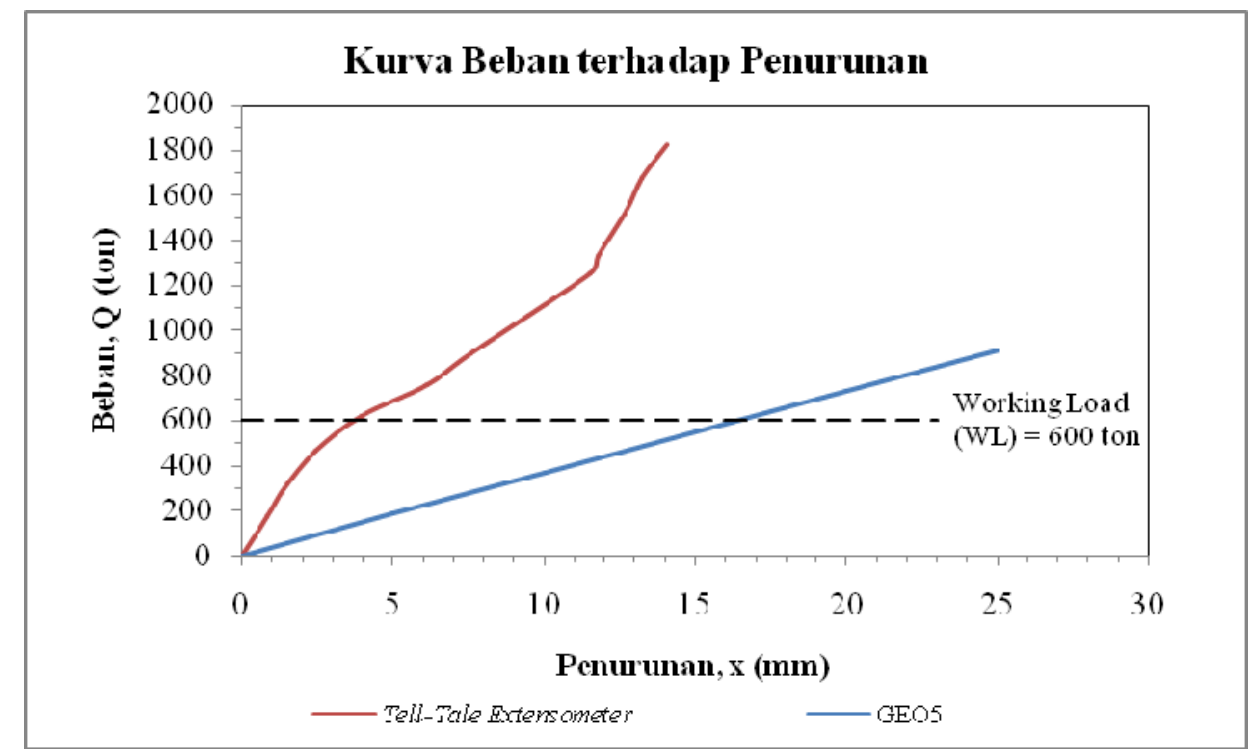

Gambar 6. Kurva Perbandingan Beban terhadap Penurunan 
Hasil penurunan dan perbedaan hasil analisis dari uji beban tiang terinstrumentasi dan program GEO5 terdapat pada Tabel 5.

Tabel 5. Tabel Penurunan Hasil Uji Beban Tiang Terinstrumentasi dan Program GEO5 pada Beban Kerja 600 ton

\begin{tabular}{|c|c|c|}
\hline Analisis & $\begin{array}{c}\text { Settlement } \\
(\mathrm{mm})\end{array}$ & $\begin{array}{c}\text { Perbedaan } \\
(\%)\end{array}$ \\
\cline { 1 - 2 } Uji Beban Tiang Terinstrumentasi & 3,8 & \multirow{2}{*}{76,7} \\
\cline { 1 - 2 } GEO5 & 16,3 & \\
\hline
\end{tabular}

\section{SIMPULAN}

Dari hasil analisis beban-penurunan terhadap pondasi tiang bor dengan diameter $1 \mathrm{~m}$, panjang 59,3 m, pada tanah medium silty clay, stiff silty clay, dan hard clay diperoleh simpulan sebagai berikut:

1. Besar penurunan pada saat beban kerja (WL) 600 ton dari hasil uji beban tiang terinstrumentasi adalah sebesar 3,8 $\mathrm{mm}$ dan dari program GEO5 adalah sebesar $16,3 \mathrm{~mm}$.

2. Perbedaan penurunan hasil uji beban tiang terinstrumentasi terhadap program GEO5 sebesar 76,7\%. Hal ini menunjukkan analisis penurunan pondasi tiang dengan menggunakan program GEO5 lebih konservatif jika dibandingkan dengan hasil uji beban tiang terinstrumentasi.

\section{UCAPAN TERIMA KASIH}

Penulis mengucapkan terima kasih kepada Ir. Irawan Firmansyah, MSCE, yang telah memberikan data-data bagi penelitian ini.

\section{DAFTAR PUSTAKA}

1. Allpile User's Manual Volume 1 and 2, 2014, CivilTech Software

2. ASTM D1143-81, Standard Method of Testing Piles Under Static Axial Compressive Loads

3. Balakrishnan, E.G., Balasubramaniam, A.S., Phienwej, N., 1999, Load Deformation Analysis of Bored Piles in Residual Weathered Formation, Journal of Geotechnical and Geoenvirontmental Engineering 
4. Data Uji Beban Tiang Terinstrumentasi, CEP LTD

5. E., Joseph Bowles, (1996), Foundation Analysis and Design $5^{\text {th }}$ ed., The McGraw-Hill Companies, Inc., Singapore

6. Manual Pondasi Tiang Edisi 3, (2005), GEC, Universitas Katolik Parahyangan

7. M., Braja Das, (2011), Principles of Foundation Engineering $7^{\text {th }}$ ed., Cengage Learning, USA

8. Phienwej, N., Balakrishnan, E.G., Balasubramaniam, A.S., (1995), Performance of Bored Pile in Weathered Meta-sedimentary Rocks in Kuala Lumpur Malaysia, Asian Institute of Technology, Bangkok, Thailand

9. Prakash, Shamsher, D., Hari Sharma, (1990), Pile Foundations in Engineering Practice, John Wiley \& Sons, Inc., Canada. 